\title{
Foreign Parent Strategies, Control \\ and International Joint Venture Performance
}

\author{
Nguyen Huu Le \\ University of Vaasa \\ PO Box 700, 65101 Vaasa, Finland \\ Tel: 358-6-324-5289Ｅ-mail: nghl@uwasa.fi \\ Larimo Jorma \\ University of Vaasa \\ PO Box 700, 65101 Vaasa, Finland \\ Tel: 358-6-324-8253 E-mail: jla@uwasa.fi
}

This project is a part of the "International joint venture behavior, strategies, and performance" project at the Department of Marketing, University of Vaasa funded by the Academy of Finland for the years 2006-2008. The project leader is Professor Jorma Larimo.

\begin{abstract}
This paper develops and expands upon an important connection between foreign parent firm strategies, the manner in which they control their international joint ventures (IJVs), and the performance of those IJVs. Parent firms' strategies refer to strategic motives, importance, focus, and competitiveness. Foreign parent firm control is conceptualized across three dimensions including the control mechanism, the control focus, and the extent of control. Our empirical evidence is based on the survey data collected from Finnish firms that established IJVs with local firms in the 1990s. The empirical evidence show different strategies used in IJVs by foreign parent firms required different control structures in IJVs. In addition, the firms that adapted control structure in their IJVs according to their strategies were more satisfied with their IJV performance than those who did not. As such, the paper takes a step further from just being concerned about parent firms' strategies and moves our thinking toward understanding how to realize such strategies through proper control.
\end{abstract}

Keywords: Strategy, Control, International Joint Venture, Performance

\section{Introduction}

In the last decades, establishment of IJVs has become a major strategy for firms entering international markets (Ding, 1997; Duan, 2007; Dunning, 1995; Li, 2003; Meschi \& Riccio, 2008), and an important strategic approach for coping with global competitive pressure (Kwon, 2008). However, researchers have pointed out that between $30 \%$ and $70 \%$ of the total number of IJV established eventually break up (Hennart, Kim \& Zeng, 1998; Yeheskel, Newburry \& Zeira, 2004). The literature of international business shows that control is one of the biggest challenges that parent firms face when entering IJVs (Geringer \& Hebert, 1991), and plays an important role in IJV successes, or failures (i.e. Groot \& Merchant, 2000). Already more than 15 years ago, Geringer and Hebert (1989) proposed that future research should broaden the critical considerations and implications of control in terms of mechanisms, control extent, and control focus. Later on, Raswamy, Gomes, and Veliyath (1998) have also suggested the necessity to examine a wider array of IJV control through in-dept investigations. More recently Barden, Steensma, and Lyles (2005) have added to the debate and suggested that further research is needed to investigate the "fit" between parent firms' strategies and their control systems.

The purpose of the present study is to analyze the relationships between foreign parent strategies, control and performance in IJVs. The research puzzle is addressed through the following questions: 
1) How do foreign parent firms configure the control structure in their IJVs to implement their strategies?

2) What are the relationships between foreign parent control structure in IJVs and the IJV performance?

In the present study, an IJV is regarded as a separate entity formed by a multinational company (MNC) or multinational companies and a local firm or local firms either through greenfield investment or partial acquisitions. In the following sections, we conceptualize the IJV control along three dimensions including mechanism, focus, and extent. Then, we develop hypotheses regarding foreign parent strategies, IJV control and performance. We conclude by pointing out the implications for researchers and managers, and indicate some opportunities for future research.

\section{Conceptualization of IJV control}

In the organizational literature, management control means the process by which an organization influences its members and units to work in ways that meet the organizational objectives (Glaister \& Buckley, 1998). According to Child et al. (2005: 15), control is a central aspect of management, and essential in any system that holds managers accountable for their actions and decisions. The main purpose of control is to attain predictability and critical information on IJV operation through some regulatory means (Makhija \& Ganesh, 1997), and thus to safeguard the parent firm's interests. In the present study, the control of IJVs is defined as the influence of the foreign parent firms on the operations of the IJVs (Ding, 1997). Furthermore, researchers have acknowledged that control systems are complex and multidimension (see e.g Das \& Teng, 1998; Geringer \& Hebert, 1989; Lu \& Hebert, 2005). Unfortunately, existing research tends to focus on only one dimension. To be able to capture the dynamic nature of IJV and conduct IJV control research thoroughly, this study adopts the multidimensional approach of control (mechanism, focus, and extent) advocated by Geringer and Hebert's (1989). In this section, these control dimensions are elaborated upon.

\subsection{Control mechanisms}

Control mechanisms are structural arrangements deployed to determine and influence what an organization's members do (Geringer \& Hebert, 1989). Control mechanisms consist of a variety of mechanisms including formal and social controls that are available for firms exercising effective control to protect their interests in IJVs (Geringer \&Hebert, 1989; Groot \& Merchant, 2000). Formal control depends on hierarchies, standards, codified rules, procedures, goals, and regulations that specify desirable patterns of behavior (Das \& Teng, 1998) aimed directly at protecting the assets of parent firms (Fryxell et al., 2002). Formal control mechanisms help to decrease the potential for opportunisms by controlling the assets through hierarchical means (Mjoen \& Tallman, 1997). Social control is designed to promote expectations and mutual commitments through which the IJV managers learn to share the common attitudes and knowledge of the parent organization. Social control refers to mechanisms such as personal relations, informal communication, information exchange and training, mentoring, and development of a common organizational culture that foster shared values and norms without explicitly restricting the behavior of the targeted people by those social controls (Schaan, 1983; Das \& Teng, 1998; Fryxell et al., 2002).

\subsection{Control focus}

Regarding the control focus, partners can choose to have a broad control focus and attempt to exercise control over the entire range of the IJV's activity, or they can have a narrow control that focuses on only one or two areas in IJV activities which they consider the most critical (Geringer \& Hebert, 1989; Groot \& Merchant, 2000). The most critical areas in IJVs are often: 1) Marketing, sales, and distribution; 2) Procurement; 3) General management and operation; 4) Finance and accounting; 5) R \& D; 6) Production and quality; and 7) Human resources (Glaister et al., 2005). Depending on factors such as the parent firm's competencies and the goals of IJV activities, parent firms may focus their control on technology-related or market related activities (Child et al., 2005).

\subsection{Control extent}

Control extent refers to the tightness of control which is exercised (Geringer \& Hebert, 1989). Tightly controlled organizations tend to be strict with respect to their employee's punctuality, and detail oriented, and precise in operation. Tight control can be effected through any mechanism that provides a partner with a high degree of certainty that personnel in the IJV will act as the given partner wishes. According to Child et al. (2005), the tightness of control is reflected in frequent and precise reporting. Controls can be tightened by more intensive training of IJV employees in production and management techniques. These dimensions of IJV control will be used as the IJV control structure when we discuss how foreign parent firms strategies determine the IJV control structure in the following section.

\section{Foreign parent strategies and IJV control}

Gaining management control over an IJV is one way to ensure that one's strategic objectives are actively pursued, and to actively monitor and curb possible opportunism by one's partner. Johnston (2005) argued that different subsidiary tasks are associated with different levels of parent control. Previous researchers proposed that foreign parent firms entering into IJVs should design their IJV control structure based on their strategic motives, strategic importance (Chalos \& O'Connor, 1998), strategic focus (Li, 2003), and competitive strategy (Govindarajan \& Fisher, 1990). 
However, the existing research does not show any links between the partner's strategies and the choice of the IJV's control system (Groot \& Merchant, 2000: 583; Barden et. al, 2005). This section, therefore, attempts to fill in this gap.

\subsection{Strategic motives}

Previous researchers suggested that the strategic motives of parent firms determine their control in IJVs (e.g. Calantone \& Zhao, 2001). Foreign parent firms enter into joint ventures with different motives. According to Harrigan (1985), foreign parent firms form IJVs to generate internal benefits, competitive benefits, and strategic benefits. Kogut (1988) suggests three main motives for IJV formation including cost reduction, strategic behavior, and learning. To find a link between parent strategies and their control within the scope of this paper, we adopt the classification of motives proposed by Makino (1995): 1) accessing the partners' proprietary resources, and 2) achieving economies of scale and scope.

The primary motive for foreign parent firms forming IJV is to gain access to a local firm's proprietary resources including both firm-specific knowledge and country specific knowledge. Whilst, local firms may lack management know-how and technology (Luo et al., 2001), they often contribute their country specific knowledge, land, and manufacturing facilities (Killing, 1983). According to resource dependency theory, if the access that local parent firms contributing to the IJVs have is critical to the IJVs success, the local parent firms have a better position from which to negotiate for more control over IJVs (Mjoen \& Tallman, 1997). Thus, they leave foreign firms less control in the IJVs. Foreign firms, as a result, acquire their control through social control and by concentrating their control on the areas where they contribute most to the IJVs. Therefore, we expect that:

Hypothesis 1a: Foreign parent firms entering into an IJV to gain access to local parent firm proprietary resources are more likely to use a narrow, social, and loose form of control over the IJV.

Another common motive for a foreign parent firm to enter IJVs with local firms is to gain economies of scale and scope. For this purpose, foreign parent firms are often manufacturing firms and they just expect the local parent firms to merely supply them with cheap labor, and existing facilities such as land and/or a factory (Killing, 1983). This contribution by local parent firms can simply help to reduce the production costs of the IJVs (Kogut, 1988). For foreign parent firms entering into IJVs with this motive, the most important issue is the quality of the product of the IJV (Chalos \& O'Connor, 1998). In addition, the success of a joint venture depends on the fit between the parent criteria for success and how well the parent control specific activities related to its criteria for success (Schaan, 1983). Thus, foreign parent firms may narrow down their control to focus on the quality issue of the IJVs' output. Furthermore, by focusing their control on some specific activities and loosening control over the rest of the IJV activities for local parent firms, foreign parent firms give incentives for local parent firms more chance to involve in and contribute to the activities of the IJVs. Giving up overall control and maintaining formal control in just some key areas of the IJV also helps to reduce the costs associated with excessive control. This may help to reduce the level of conflict and increase the cooperation between foreign and local parent firms. As a result, we propose:

Hypothesis 1b: Foreign parent firms entering to IJVs with local firms to gain economies of scale and scope are likely to exercise narrow, formal, and loose control over IJVs.

\subsection{Strategic importance}

An IJV can play an important role in the parent's value chain when it is a vital source for the parent firm's output, or a repository for the parent firm's core competencies (Johanson et al., 2001). Therefore, IJVs may be established to improve the strategic positioning of the foreign parent firms (Glaister \& Buckley, 1996). With respect to the strategic importance, researchers (Bartlett \& Ghoshal, 1986; Koza \& Lewin, 1998) have previously argued that IJV parents do not often deem the partnership to be of equal important in their overall strategic portfolio, and that a partner that has a large strategic interest in an IJV may indeed prefer a broad control. According to Yan and Gray (2001), those firms for which the IJVs are of greater strategic importance than for their partners will have a greater stake in the venture and may negotiate strongly for control. Green and Welsh (1988) pointed out that when the IJVs play a key role in the parent firm's revenue or their inputs supplying, the parent firms will try to maintain such inputs and revenue under their tight control. In the same vein, Hennart (1988) suggested that the parent firms will seek for dominant control over the IJVs or convert these into wholly owned subsidiaries when the IJVs become strategically important to them.

Merchant and Groot (2000) found that when the foreign parent firms had a broader set of objectives for an IJV, their focus on control was broad. In contrast, they also argued that when firms use an IJV to diversify their offerings, they tend to employ a relatively loose control. Boyacigiller's study (1990) found that the greater the interdependence between the IJV and the headquarters, the more U.S. nationals were placed in the high-level positions in the subsidiary to manage the uncertainties. In summary, as suggested by the transaction cost theory, if an IJV is strategically important, the foreign parent firm will protect its position and reduce uncertainty to safeguard its interests. Thus, we propose:

Hypothesis 2: The more important the IJVs are to the foreign parent firms, the more likely the foreign parent firms are to exercise broad, formal, and tight control over them. 


\subsection{Strategic focus}

\subsubsection{Domestic focus}

Domestic market oriented IJVs are those that direct most of their activities towards the markets (Chalos \& O'Connor, 1998) where the IJVs are located, thus commitment and cooperation from the local partners are more important. Because foreign parent firms are probably not familiar with local tastes and local unique customer needs. The knowledge of the host environment provided by the local partners may enable suitable adaptation; and bring advantages to the IJVs (Johnston, 2005). Previous research also points out that less control from the foreign parent firms, and more influence of the local parents, are factors necessary for better performance of IJVs ( $\mathrm{Li}, 2003)$. This is especially important in those countries such as China where the local governments play an important role in joint venture activities (Beamish, 1993). Information about the local economy, politics, culture and business customs, consumer's demands and tastes, the labor force, infrastructure, raw materials, and other factors required for the operation of joint ventures are likely to be delegated to the local partner (Makino \& Delios, 1996).

In addition, Bai, Tao, and $\mathrm{Wu}(2003)$ found that if the sales of the IJVs' products are mainly focused on local markets, the control of the foreign parent firms decreases with the need for local marketing knowledge of their products. This is because the IJVs in the countries like China are often a marriage of foreign technologies and local markets. In this context, the marketing expertise for local markets is often an important contribution of the local partners, while the technological sophistication is an equivalent provided by the foreign partners. Therefore, the foreign parents oriented towards the local markets are likely to exercise less control over the IJVs because the resources important to them are obtained with the help of the local partners (Calantone \& Zhao, 2001). As a result, we propose:

Hypothesis 3a: In domestic oriented IJVs, foreign parent firms prefer to exercise a narrow, loose, and social control over the IJVs.

\subsubsection{Export focus}

In some cases the sales of the IJVs are export oriented and the local parent partners often lack competence in exporting, thus it is more efficient for the foreign parent firms to dominate the IJV operation ( $\mathrm{Li}, 2003)$. This may be because, as in case of managers in the countries of Central and Eastern Europe there is technical proficiency but a lack of experience of market-oriented management functions such as strategic planning, and especially the marketing mix (Filatotchev et al., 1996; Stephan, 2006) which play a critical role in exporting to foreign markets. Thus, to offset the risk of the lack of local managerial competence of local managers, the foreign parent firms may become directly involved in a broad range of the IJV's activities.

In addition to exporting to international markets, the foreign parent firms who often have a competitive advantage in production management (see Liker et al., 1999) have to apply tight and formal control especially over product quality, so that their products meet the international standards and are able to compete in the international markets (Chalos \& O'Connor, 1998; Li, 2003). Furthermore, export orientated subsidiaries often face risks related to security and enforcement of contractual export obligations such as timely deliveries and quality standards. Thus we expect:

Hypothesis 3b: In export oriented IJVs, the foreign parent firms prefer to exercise a broad, tight, and formal control over the IJVs

\subsection{Competitive strategy}

The competitive strategy used in the present study to investigate the dimensions of foreign parent firms' control dimensions over their IJVs in accordance with their competitive strategies, is based on the framework by Porter (1980). He divides competitive strategies into two main forms: 1) the low cost strategy, and 2) the differentiated strategy.

\subsubsection{Low cost strategy}

Many times, the foreign firms operating in foreign markets often have to adapt their strategies to align with the local consumer's income and therefore, often use a low cost strategy. This competitive strategy is characterized by: 1) vigorously pursuing cost reduction, 2) enforcing all the possible economies of scale, 3) acquiring process engineering skills, or skills needed in order to design and plan efficiently, 4) bring routine to the task environment, and 5) producing a standard, undifferentiated product (Porter, 1980). The main focus of this strategy is on the standard product with the routine task environment or in other words, cost control focus. The foreign parent firms motivate their delegates in the IJVs to measure these costs. Because the outcome is observable under the low cost strategy, the foreign parent firms will try to avoid costs by not engaging in further control, such as social control. Child et al. (2005) suggested that in the case of activities with a measurable output, control can be exercised through formal monitoring systems. Because control incurs both direct and indirect costs (Child, Yan \& Lu, 1997), the foreign parent firms, which apply a low cost strategy for their units, gain a higher effectiveness by narrowing down their focus to some of formal control like output control (Govindarajan \& Fisher, 1990). In summary we suggest: 
Hypothesis 4a: The foreign parent firms prefer to exercise a narrow, formal, and loose control over low-cost strategy oriented IJVs.

\subsubsection{The differentiation strategy}

Foreign parent firms which adopt this strategy for their IJVs will target producing a unique product. Thus, the IJV should have a unique task of producing and marketing. In this kind of competitive strategy, knowledge management may not be a simple task for foreign parent firms with different subsidiaries. Differentiated products are often the result of a complex interplay between all the parts of the MNCs, thus parent firms may need to act as foci for tapping the resources of the total network (Birkinshaw \& Hood, 2000). As a result, a close relationship between parent firms and the IJVs is necessary (Johnston, 2005). Miller (1988) maintains that the task environment of the units which adopted a differentiation strategy is more complex than that those adopting a low cost strategy. To cope with this, the foreign parent firms need to engage more in the IJV operation and thus to impose a broader control on them. Govindarajan and Fisher (1990) suggested that the units which are to manufacture unique and high quality products may gain a higher effectiveness when the parent foreign firms exercise more control over behavior which may be formatted by formal control. In a similar manner, Child et al. (2005) argued that, when IJVs focus on complicated marketing work, the most appropriate option is formal control which is based on behavioral assessments of how the activities are being carried out. Based on the above we expect that:

Hypothesis 4b: Foreign parent firms prefer to exercise a broad, formal, and tight control over the differentiation strategy oriented IJVs.

\subsection{Links between the foreign parent firms' strategies, control, and IJV performance}

Child and Yan (2003) argued that parent firm control permits the effective use of whatever strategic resources that the parent firms have in the IJVs. O'Donnell (2000) proposes that the fit between subsidiary strategy and the subsidiary control mechanism, such as incentives for subsidiary managers, can help the subsidiary achieve performance objectives. Johnston (2005) studies the relationship between headquarters and subsidiaries, and finds that different subsidiary tasks were associated with different levels of subsidiary autonomy. In other words, as parent firms set different tasks and targets for their subsidiaries they may exercise different levels of control over them. Dymsza (2002) analyzed the successes and failures of IJVs in the developing countries. He pointed out that parent firms which have a marketing oriented strategy emphasizing the product differentiation, segmentation of markets, trademarks and brand names, and promotion and selling will strive to control these activities in the IJVs. Lorange et al. (1986) maintain that through exercising a proper IJV control structure, foreign parent firms can make sure that their strategies are effectively implemented, and their resources are efficiently utilized for enhancing the IJV performance. Thus, we expect that:

Hypothesis 5: The foreign parent firms which adapt their control structures in the IJVs according to their strategies will enjoy a better IJV performance than those that do not.

\section{Sample description and measurement}

The study here is a part of an on-going research project focusing on IJV behavior, strategies, partner selection, control structure, and performance of Finnish firms. The target firms and investments were identified as follows: 1) The FDI data base collected by the project leader starting from the late 1980s based on press releases regarding IJVs published in several Finnish business magazines and newspapers, 2) Annual reports and websites of the 250 largest Finnish firms as reported by the leading business magazines, 3) based on the earlier surveys focusing on IJVs and wholly owned subsidiaries of Finnish firms conducted by the project leader. From the resources, we identified 340 IJVs qualifying IJVs formed by Finnish firms since 1985 and in operations at least until 2002. The qualifying 340 IJVs involved 250 Finnish parent firms. Of those 250 firms, several firms were very difficult to contact either because they had been restructured or gone out of business. The aim of contacting the firms was primarily to identify the best informants. In some firms there was no longer anyone employed with sufficient knowledge required to inform. This left a total of 200 Finnish parent firms. Due to time and cost constraints a postal questionnaire and online web survey were used to gather the data.

The participants were those managers who directly involved in the establishment and operations of the IJVs. To enhance the quality of the data, the respondents were contacted by phone in December 2006 to explain the key points of the study and the questionnaires. In exchange for their cooperation with the study and to provide motivation and accurate responses, the respondents were assured of anonymity and were promised a summary report of the findings and also participated in a draw for three gifts. After one reminder at the end of the January 2007, at the end of February, 54 questionnaires were collected from 49 participating firms giving responses relating to $54 \mathrm{IJVs}$, a response rate of $24,5 \%$ which is relatively similar to that of earlier respective studies in Finland (see Larimo \& Rumpunen, 2006). The sample was carefully examined for any systematic response bias using t-tests. Respondents and non-respondents were compared across their age, size, international experience, and IJV experience. No statistically significant difference was 
found. Thus, there was not response bias to be found in the final sample. After taking out the uncompleted questionnaires, the final sample related to 49 IJVs.

Among these IJVs, 45\% were established in 1988-1995, and 55\% in 1996-2006; $53 \%$ through acquisitions, and 47\% through greenfield investment; $76 \%$ involved 2 partners and $24 \%$ involved 3 partners; $61 \%$ were established with indefinite duration, $22 \%$ with a duration of less than 5 years, and $17 \%$ stated to have a duration of more than 5 years; $41 \%$ had a degree of Finnish ownership of between 10\%-49\%, 10\% had equal ownership, and $49 \%$ had Finnish majority ownership at establishment; $71 \%$ were located in emerging economies, and $29 \%$ in developed economies; $63 \%$ dealt with industrial products, $27 \%$ with consumer products, and $10 \%$ offered both consumer and industrial products.

All three control dimensions were measured with a 5 point-scale. Based on the list of different mechanisms and focus areas provided, the respondents were asked to assess their 1) method of monitoring and control, and 2) their focus of monitoring and control (Cronbach's Alpha $=0.92$ ). The measurement of strategies used by parent firms in IJVs was based on a 5 point-scale with $1=$ "not important at all" to $5=$ "very important" where Cronbach's Alpha $=0.95$. The measure of IJV performance was also based on a 5 point-scale, the respondents were asked if they were satisfied with IJV performance on both financial and total performance scales with $1=$ "very unsatisfied" to $5=$ "very satisfied" where Cronbach's Alpha $=0.94$.

\section{Results}

The empirical data has been analyzed based both on descriptive statistics and on testing statistics. In order to test hypothesis 1 to 4, a correlation matrix including parent strategies and different control structures has been computed. The results are shown in table 1 .

\subsection{Parent strategic motive and IJV control}

Of 49 respondents, 18 mentioned their main strategic motive in entering to IJVs to be gaining access to local firms, and especially their management skill set. Of these 18 respondents, almost $90 \%$ exercised narrow control, over $80 \%$ exercised loose control, and almost $80 \%$ exercised social control over their IJVs. In addition, table 1 shows statistically positive correlations between this gaining access strategy and narrow, social, and loose control structures. Thus, the result supports the hypothesis 1a: when foreign parent firms enter into IJVs to access local firms' resources, they prefer more social, narrow, and loose control over their IJVs. There were 31 firms who mentioned their main motive of entering IJVs to be to gain economies of scale. Of these 31 firms, more than $80 \%$ of foreign parent firms used formal control, and about $70 \%$ of parent firms used narrow and loose control with their IJVs. Table 1 also shows statistically positive correlations between a strategy directed towards gaining economies of scale and scope and narrow, formal, and loose control structures. Thus, the result supports hypothesis $1 \mathrm{~b}$ : foreign parent firms prefer formal, narrow, and loose control when they enter IJVs to gain economies of scale and scope.

\subsection{Strategic importance of IJVs and IJV control}

When asked to consider the strategic importance of their IJVs, 32 respondents mentioned that IJVs are strategically very important for the parent firms. Of these 32 responses, almost $85 \%$ of the companies concerned exercised formal control, and about $75 \%$ were found to exercise broad and tight control over their IJVs. In addition, table 1 shows statistically positive correlations between strategic importance and broad, formal, and tight control structures. Thus the result supports hypothesis 2 that the more important the IJVs are to the parent firms, the more likely it is that the foreign parent firms exercise more formal, broad and tight control over their IJVs.

\subsection{Parent firm strategic focus and IJV control}

There were 26 respondents who mentioned that the strategic focus in their IJVs was on exporting to other markets, and 23 respondents mentioned their focus on the domestic markets. Within the group of 26 respondents focused on export, 17 respondent firms (65\%) exercised broad control over their IJVs and $21(80 \%)$ respondent exercised tight control over their IJVs, and further $22(85 \%)$ of foreign firms exercised formal control. Table 1 shows statistically positive correlations between export focus strategy and a broad, formal, and tight control structure. Thus, the result supports hypothesis $3 \mathrm{~b}$ that IJVs with an export focused strategy, foreign parent firms prefer to exercise broad, tight and formal control over their IJVs. There were 23 respondents who described their strategies as being domestically focused. Among these, 19 (82\%) exercised formal control, 8 (35\%) employed narrow control, and 10 (43\%) used loose control in their IJVs. Table 1 does not show any statistically significant relationship between domestic focus strategy and narrow, social, and loose control. Thus the result does not support hypothesis $3 \mathrm{a}$.

\subsection{Parent firm strategic competitiveness and IJV control}

Twenty-one respondents mentioned that they implemented a low cost strategy, and 28 respondents mentioned that they applied a differentiation strategy in their IJVs. Among the 21 respondents with a low cost strategy, over $80 \%$ exercised formal, narrow, and loose control over their IJVs. Table 1 shows statistically positive correlations between low cost strategy and formal, narrow, and loose control structures. Thus, the result supports hypothesis $4 \mathrm{a}$ that foreign parent 
firms prefer to exercise formal, narrow, and loose control over low cost oriented IJVs. Among the 28 respondents who employed a product differentiation strategy more than $80 \%$ exercised broad control and formal control, and over $75 \%$ respondents applied tight control to their IJVs. In addition, Table 1 shows statistically positive correlations between the differentiation strategy approach and broad, formal, and tight control. This result supports hypothesis $4 \mathrm{~b}$ that foreign parent firms prefer to exercise broad, formal, and tight control over their differentiation strategy IJVs.

Table 1 about here

\subsection{Parent firm's strategies, control, and IJV performance}

There were 22 respondents who answered that their firms have adapted their control techniques according to their strategies. These 22 firms had a mean of total performance rating of 4.1 and financial performance rating of 3.7 (1= "very unsatisfied" to $5=$ "very satisfied") which indicates a positive relationship between parent firm's adaptation of control systems to their strategies and IJV performance. The remaining 27 firms which did not adapt their control systems to their strategies had a mean result of 2.6 for total performance and 2.5 for financial performance.

In addition, to testing hypothesis 5 statistically, a chi-square test was used. The purpose of the method is to determine how well an observed set of data fits an expected set of hypotheses. The method was used to examine the differences with categorical variables and the relationships between internal factors (e.g. parent strategies) and IJV control structures, and IJV performance. The results of the chi-square test show a strong positive relationship between parent firm's strategic choices, their control structure, and IJV performance (see table 2). Therefore, the results support the hypothesis 5 that supposed that the foreign parent firms which adapt their control structures in the IJVs according to their strategies will have a better IJV performance level than those that do not. It is worth noting that the results support hypothesis 5 based on both performance measures - total performance and financial performance.

Table 2 about here

\section{Implications}

Our empirical evidence shows that different strategies used in IJVs by foreign parent firms required different control structures. In addition, the firms that adapted the control structure employed in their IJVs according to their strategies were more satisfied with their IJV performance than those who did not. The present study contributes to the existing IJV knowledge by offering a link between parent firm strategy and control. To expand on that, most foreign parent firms want a high level of control that is consistent with their bargaining power (Calantone et al., 2001). However, the present study suggests that, to succeed in target markets, foreign parent firms must have a comparable IJV control structure that fits their strategies. This finding is consistent with Lynch (1993) and Kumar and Seth (1998) who argued that the IJV control structure reflects the parent firm's strategy. Moreover, the newness of this study is the extension of previous research. Although previous research (e.g. Kumar \& Seth, 1998; Lynch, 1993) suggested the importance of a compatibility between strategy and control, it failed to point out which control structures are needed for which strategies. This study extends the previous research by specifying which kind of control structure would fit with different strategies. More specifically, for the purpose of gaining economies of scale and scope when committing a joint venture with local firms, the present study suggests that the foreign parent firms should focus their control on the most critical issues in IJVs, such as product quality control. Beside these critical areas, the foreign parent firms can allow the local firms to be in charge of other areas in the IJVs, thus they can reduce the costs associated with an excessive control structure, and at the same time, motivate the local parent firms to utilize their expertise. The foreign parent firms often use the IJV as a base for manufacturing units and then export the output to other markets. The present study points out that it is more efficient for the foreign parent firms to dominate the IJV operation. This is because managers in some countries, for example in Central and Eastern Europe, are often technically proficient, but inexperienced with market oriented management functions, such as strategic planning and the marketing mix which are fundamental to successfully exporting to developed markets. Thus, the present study suggests that broad and tight control help the foreign parent firms not only to ensure the IJV's output meets the international quality standards, but also to utilize their advanced management know-how of export best practice.

For the IJVs that are strategically important to the foreign parent firms, broad, formal, and tight controls are likely to be the effective ones. This finding confirms Johnston's (2005) work maintaining that when the subsidiaries are big and play an important role, the parent firms impose progressively more hierarchical, or formal control mechanisms, on their subsidiaries. Regarding the competitive strategy, for the IJVs which contribute to a low cost strategy, the parent firms tend to use narrow, formal, and loose control methods in their IJVs. However, when the foreign firms adapt differentiation as the competitive strategy for their IJVs, broad, formal, and tight controls may be the most effective to manage the IJVs. Differentiated products are the result of a complex interplay between all the parts of the firm, so that the foreign parent firms need to act as a center for tapping the resources of the total network. As a result, intensive control is deemed necessary. Social control mechanisms can not be used in both strategies because the structure will take longer to build, and be extremely costly (considering social events, such as outdoor activities, parties, extensive 
training, building personal relationships, etc.). This finding extends the previous research by Gullander (1976), who suggested that an appropriate control structure allows parent firms to integrate the IJV's activities with its strategies. To expand on that suggestion, this study has specified which kinds of IJV control design structures are most suitable for different strategies. From another perspective, the findings contribute to existing knowledge by countering Johnston's argument that when the subsidiaries pursue a cost leadership strategy, the headquarters maintain tight control over subsidiaries' activities (Johnston, 2005: 36).

Figure 1 about here

\section{Suggestions for further research}

The present study offers several opportunities for further studies. IJV structure is the result of a negotiation process between foreign and local firms (Kogut, 1988). Because this study excluded the negotiation between foreign firms and local firms for control of the IJVs, further study could investigate the influence of this element on IJV control. In addition, there are other variables that can affect IJV control, such as operating environments (Fey \& Beamish, 2000), cultural similarity (Lin \& Germain, 1998). These factors also need to be investigated. Since the data collected in the present study is limited to IJVs formed by Finnish firms, further empirical study using the framework of this study could also collect data from different countries in Asia, Europe, and America. Then, the findings would need to be compared in order to provide more generalizable results. Moreover, as the IJVs evolve over time, further study using the presented framework in order to investigate the fit between the foreign parent's strategies and the control structures utilized during the life cycle of the IJVs may be of great interest.

\section{References}

Bai, C.-E., Tao, Z. \& Wu, C. (2003). Revenue Sharing and Control Rights in Team Production: Theories and Evidence from Joint Ventures. William Davidson Working Paper Number 563, 1-51, The University of Michigan Business School.

Barden, J. Q., Steesma, H. K. \& Lyles, M. A. (2005). The influence of parent control structure on parent conflict in Vietnamese international joint ventures: an organizational justice-based contingency approach. Journal of International Business Studies, 36, 157-174.

Bartlett, C. A. \& Ghoshal, S. (1986). Tap your subsidiaries for global reach, Harvard Business Review, 6, 87-94.

Beamish, P W. (1993). The characteristics of joint ventures in the People's Republic of China. Journal of International marketing, 1 (2), 29-48.

Birkinshaw, J. \& Hood, N. (2000). Characteristics of foreign subsidiaries in industry clusters. Journal of International Business Studies, 31 (1), 141-54.

Boyacigiller, N. (1990). The role of expatriates in the management of interdependent, complexity and risk in multinational corporations. Journal of International Business Studies, 21 (3), 357-381.

Calantone, R. J. \& Zhao, Y. S. (2001). Joint ventures in China: A comparative study of Japanese, Korean, and U.S. partners. Journal of International Marketing, 9 (1), 1-23.

Chalos, P. \& O’Connor, N. G. (1998). Management controls in Sino-American joint ventures: a comparative case study. Managerial Finance, 24 (5), 53-72.

Child, J., Faulkner, D. \& Tallman, P. B (2005). Cooperative Strategy. Oxford University Press, 215-247.

Child, J. \& Yan Y. (2003). Predicting the performance of international joint ventures: an investigation in China. Journal of Management Studies 40 (2), 283-320.

Child, J., Yan, Y. \& Lu, Y. (1997). Ownership and control in Sino-Foreign Joint Ventures,' in P. W. Beamish and J. P. Killing (eds.) Cooperative Strategies: Asian Pacific Perspectives (pp. 181-225). San Francisco: New Lexington Press,.

Das, T. K. \& Teng, B.-S. (1998). Between trust and control: developing confidence in partner cooperation in alliances. Academy Management Review 23 (3), 491-512.

Ding, D. Z. (1997). Control, conflict, and performance: A study of U.S.-Chinese joint ventures. Journal of International Marketing 5 (3), 31-45.

Duan J, Chuanmin S. (2007). Ownership, control, and performance of U.S.-China joint ventures: A longitudinal study. Journal of Applied Management and Entrepreneurship 12 (1) 25-35

Dunning, J. H. (1995). Reappraising the eclectic paradigm in the age of alliance capitalism. Journal of International Business Studies, 26, 461-493. 
Dymsza, W. (2002). Successes and Failures of Joint Ventures in Developing countries: Lessons from Experience, Book chapter in Cooperative Strategies in International Business, (pp. 403-424), edited by Contractor, F. J. and Lorange, P., New York: Lexington Books.

Fey, F.C. \& Beamish, W.P. (2000). Joint Venture Conflict: The case of Russian International Joint Ventures. International Business Review, 9 (2). 139-162.

Filatotchev, I., Hoskisson, R., Wright, M. \& Buck, T. (1996). Corporate Restructuring in Russian Privatizations: Implications for US Investor. California Management Review 38 (2): 87-105.

Fryxell, G., Dooley, R. S. \& Vryza, M. (2002). After the ink dries: The interaction of trust and control in US-based international joint ventures. Journal of Management Studies, 39 (6), 865-886.

Geringer, J. M. \& Hebert, L. (1989). Control and performance of international joint ventures. Journal of International Business Studies, 19 (2), 235-254.

Geringer, J. M. \& Hebert, L. (1991). Measuring Performance of International Joint Ventures, Journal of International Business Studies, $2^{\text {nd }}$ quarter, 249-264.

Glaister, K. W. \& Buckley, P. J. (1998). Management-performance relationships in UK joint ventures. International Business Review 7, 235-257.

Glaister, K. W., Husan, R. \& Buckley, P. J. (2005). International joint ventures: an examination of the core dimensions. Journal of General Management, 30 (4), 43-72.

Govindarajan, V. \& Fisher, J. (1990). Strategy, control systems, and resource sharing: effects on business unit performance. Academy of Management Journal, 33 (2), 259-285.

Green, S. \& Welsh, M. (1988). Cybernetics and dependence: Reframing the control concept. Academy of Management Review, 13, 287-231.

Groot, T \& Merchant, K. A. (2000). Control of International Joint Ventures. Accounting, Organizations and Society, 25, 579-607.

Gullander, S. (1976). Joint ventures and corporate strategy. Columbia Journal of World Business, 104-114

Harrigan, K. R. (1985). Strategies for joint ventures. Lexington, MA: Lexington Books.

Hennart, J.-F. (1988). A transaction costs theory of equity joint ventures. Strategic Management Journal, 9 (4), 361-374.

Hennart, J.-F., Kim, D.-J. \& Zeng, M. (1998). The impact of joint venture status on the longevity of Japanese stakes in U.S. manufacturing affiliates. Organization Science, 9 (3), 382-395.

Johnson, J. L., Cullen J. B., Sakano \& Bronson, J. W. (2001). Drivers and outcomes of parent company intervention in IJV management: a cross-culture comparison. Journal of Business Research, 52, 35-49.

Johnston, S. (2005). Headquarters and Subsidiaries in Multinational Corporations: Strategies, Tasks and Coordination. Palgrave Macmillan, Hampshire, NewYork.

Killing J. P. (1983). Strategies for joint ventures success. Praeger Publishers, New York.

Kogut, B. (1988). Joint ventures: theoretical and empirical perspectives. Strategic Management Journal, 9, 319-332.

Koza, M. P. \& Lewin, A. Y. (1998). The co-evolution of strategic alliance. Organization Science, 9 (3), 255-264.

Kwon, Y,-C. (2008). Antecedents and consequences of international joint venture partnerships: A social exchange perspective. International Business Review 17 (5), 559-573.

Kumar, S. \& Seth, A. (1998). The design of coordination and control mechanisms for managing joint venture parent relationships. Strategic Management Journal, 19, 579-599.

Larimo J. \& Rumpunen S. (2006). Partner selection in international joint ventures. Journal of Euromarketing 16 (1/2), $119-137$.

Li, X. (2003). Control in Japanese-Chinese joint ventures: Antecedent factors and effect on performance from Japanese viewpoint. Asian Business \& Management, 2 (3), 371-395.

Liker, J. K., Fruin, W. K. \& Adler, P. S. (1999). Bringing Japanese Management Systems to the United States: Transplantation or Transformation? (pp. 3-35). In J.K. Fruin and P.S. Adler (eds.) Remade in America, New York: Oxford University Press.

Lin, X. \& Germain, R. (1998). Sustaining Satisfactory Joint Venture Relationships: The role of Conflict Resolution Strategy. Journal of International business Studies, 29, 179-196. 
Lorange, P., Morton, S. M. F. \& Ghoshal, S. (1986). Strategic Control. St. Paul: West, MN.

Lu, W. J. \& Hebert, L. (2005). Equity control and the survival of international joint ventures: a contingency approach. Journal of Business Research, 58, 736-745.

Luo, Y., Shenkar, O. \& Nyaw, M.K. (2001). A dual parent perspective on control and performance in international joint ventures: lessons from a developing economy. Journal of International Business Studies, 32 (1), 41-58.

Lynch, R. P. (1993). Business Alliance Guide: The Hidden Competitive Weapon, New York: John Wiley \& Sons, Inc.

Makino, S (1995). Joint Venture Ownership Structure and Performance: Japanese Joint Ventures in Asia. Unpublished $\mathrm{Ph} \mathrm{D}$ dissertation, The University of Western Ontario, Canada.

Makino, S. \& Delios A. (1996). Local Knowledge Transfer and Performance: Implications for Alliance Formation in Asia. Journal of International Business Studies, 27 (5), 905-927.

Makhija, M. V. \& Ganesh, U. (1997). Control and partner learning in learning related joint ventures, Organization Science, 8 (5): 508-527.

Meschi, P. \& Riccio E. L. (2008). Country risk, national cultural differences between partners and survival of international joint ventures in Brazil. International Business Review 17 (3), 250-266.

Miller, D. (1988). Relating Porter's business strategies to environment and structure: Analysis and performance implications. Academy of Management Journal, 31: 280-308.

Mjoen, H. \& Tallman, S. (1997). Control and performance in international joint ventures. Organization Science, 8 (3), 257-274.

O’Donnell, S. W. (2000). Managing foreign subsidiaries: agents of headquarters, or an interdependent network? Strategic Management Journal 21, 525-548.

Porter, M. E. (1980). Competitive strategy. New York: Free Press

Schaan, J. L. (1983). Parent ownership and joint venture success: The case of Mexico. Unpublished doctoral dissertation, University of Western Ontario.

Stephan, J. (2006). Firm-Specific Determinants of Productivity Gaps between East and West German Industrial Branches. East-West Journal of Economics and Business 7 (2), 11-38

Yan, A. \& Gray, B. (2001). Antecedents and effects of parent control in international joint ventures. Journal of Management Studies, 38 (3), 393-420.

Yeheskel, O, Zeira, Y. \& Newburry, W., (1997). Factors affecting the effectiveness of equity international joint ventures in Hungary. Management International Review, Third Quarter, 37 (3), 259-279.

Yeheskel, O., Newburry, W. and Zeira Y. (2004). Significant differences in the pre- and post- incorporation stages of equity international joint ventures and international acquisitions and their impacts on effectiveness. International Business Review 13, 613-636. 


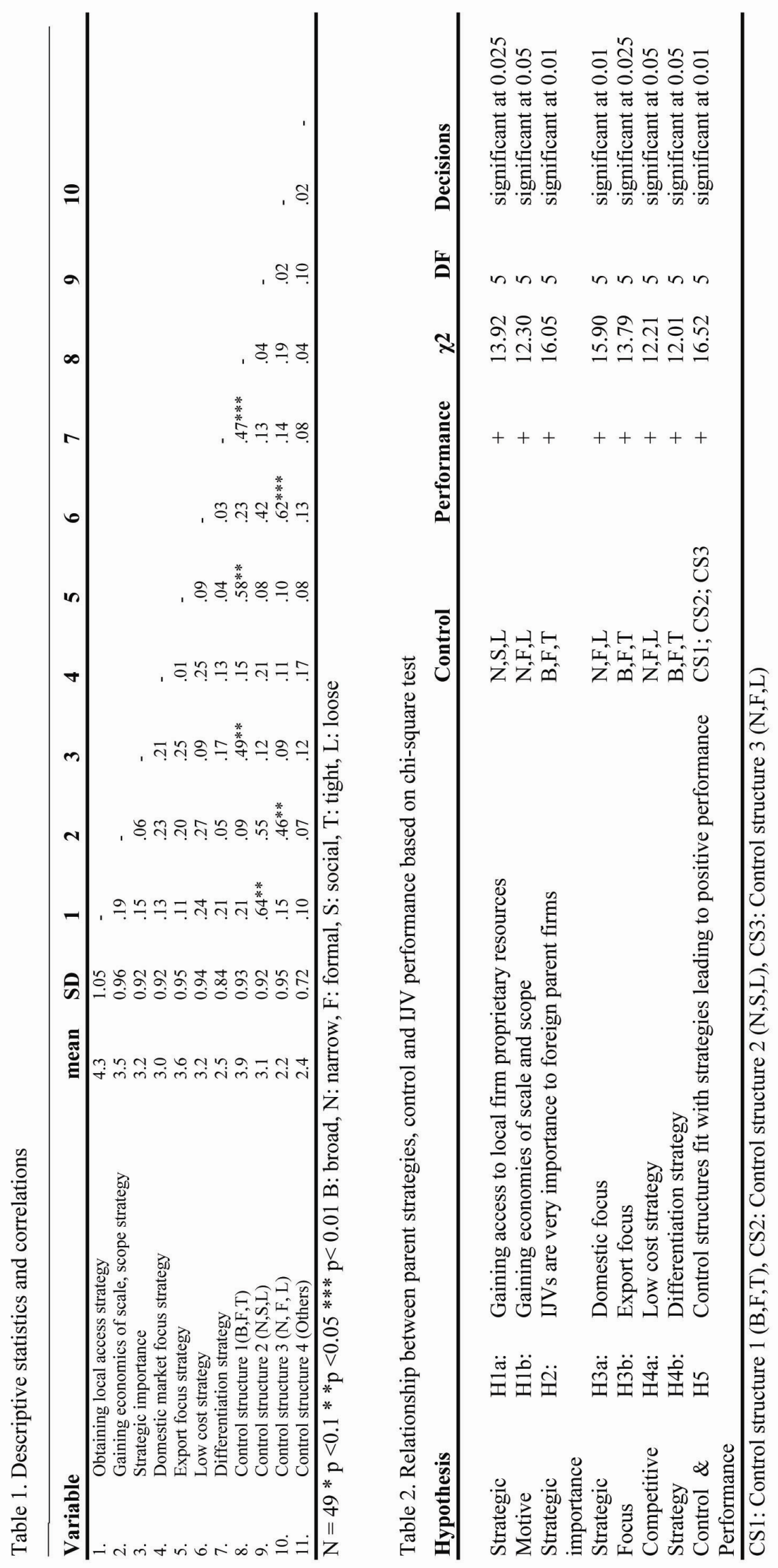




\section{Parent strategy}

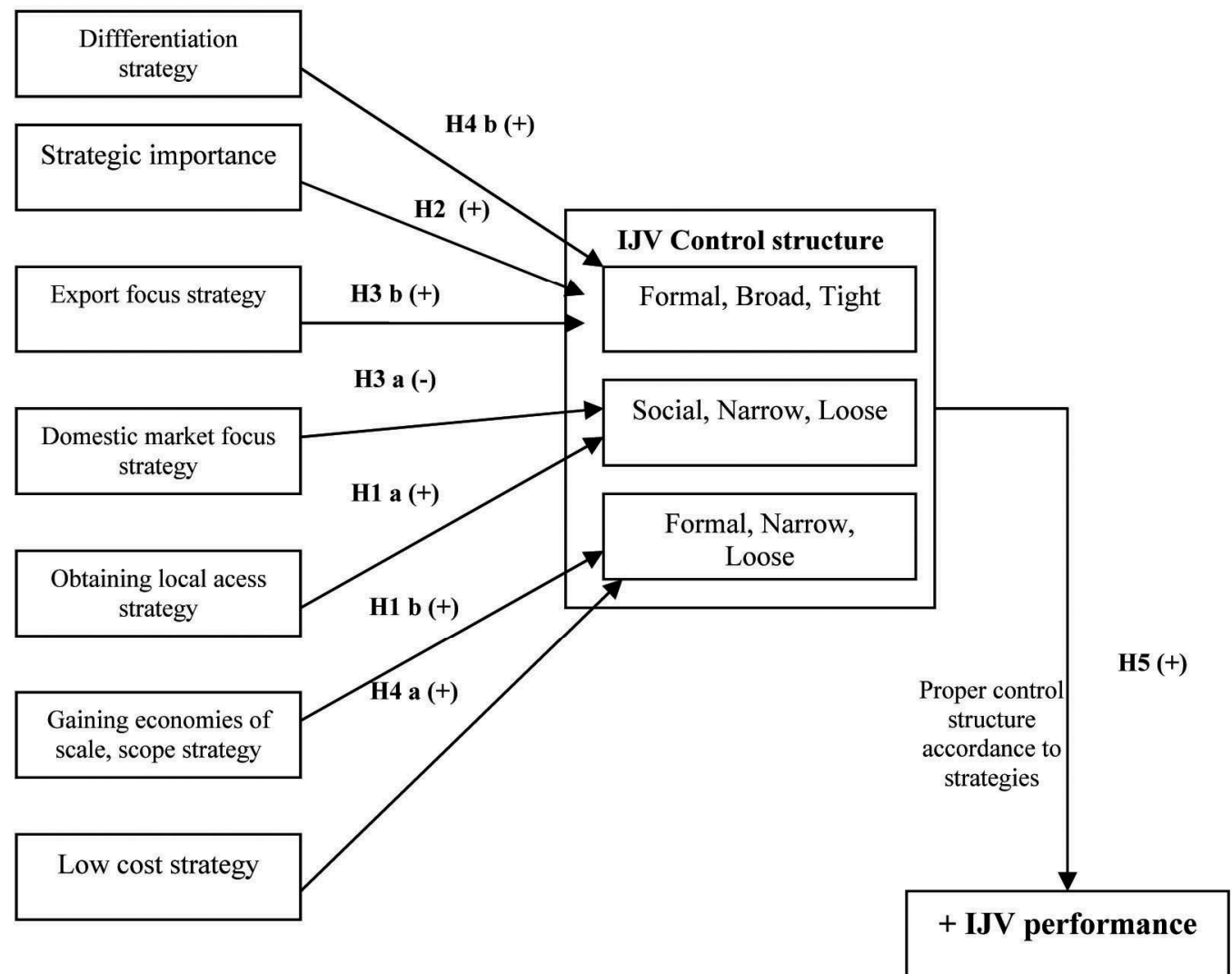

Figure 1. Relationships between foreign parent strategy, control, and IJV performance 
Appendix 1

Measurement of variables

\section{Control dimensions}

Control mechanisms

\section{Formal control}

a. Appointment of key venture personnel

b. Participation in the venture board meetings

c. Incentive plans for top management

d. Financial reports

e. Exercising veto rights at the board meetings

f. Taking part in planning JVs budgets

g. JV general manager participates in parent worldwide meetings

h. Parent-IJV face to face communication, formal meeting

i. Participation in JV's decision making

j. Control based on equity share

\section{Social control}

k. Feedback

l. Parent-venture informal socialization (informal phone call, outdoor activities)

Control focus

$\begin{array}{ll}\text { a. } & \text { International marketing } \\ \text { b. } & \text { Local marketing } \\ \text { c. } & \text { Domestic sales } \\ \text { d. } & \text { Human resources } \\ \text { e. } & \text { Procurement } \\ \text { f. } & \text { Production } \\ \text { g. } & \text { Quality control } \\ \text { h. } & \text { Prices and costs } \\ \text { i. } & \text { Financing and accounting } \\ \text { j. } & \text { Research and development } \\ \text { k. } & \text { Legal or local government relations } \\ \text { 1. } & \text { General management }\end{array}$

\section{Control extent}

degree or tightness of control which is exercised on the venture based on control mechanisms and control focus

\section{Strategies}

Strategic motive:

-Access to local firm resources

-Achieving economies of scale

Strategic importance

Strategic focus

- Domestic focus

- Export focus

Competitive strategies

- Cost leadership

- Differentiation

\section{Performance}

Financial performance

Total performance
Measured on a 5 point-scale, the respondents were asked to assess their method of monitoring and control of the IJVs. Control mechanism is formal (F) if the parents exercise control more on formal mechanisms (from a. to j. with responses value from 4 to 5). On the other hand control mechanism is social (S) if parents exercise control mechanisms more on $\mathrm{k}$. to $\mathrm{m}$. (with response value from 4 to 5).

Measured on a 5 point-scale, the respondents were asked to assess the focus areas of their monitoring and control of the IJVs. Control focus is broad (B) if parents exercise control on all or almost all the areas from a. to 1 . (with response value from 4 to 5). On the other hand, control focus is narrow $(\mathrm{N})$ if the parents exercise control on less than 3 areas (with response value from 4 to $5)$.

Control is tight $(\mathrm{T})$ if parent firms exercise more than three control mechanisms and broad control over the IJVs. Control is loose when parent firms exercise less than 3 control mechanisms and narrow $(\mathrm{N})$ control

Measured on a 5 point-scale, respondents were asked to evaluate their strategies used in IJVs with $1=$ "not important at all" to $5=$ "very important"
Measured on a 5 point-scale, respondents were asked if they satisfied with IJV performance on both financial and total performance with $1=$ "very unsatisfied" to $5=$ "very satisfied". 